\title{
NARRATIVE SUMMARIES IN ACTS OF THE APOSTLES READING OF THE THIRD SUMMARY ACCOUNT
}

\author{
Matjaž Celarc
}

Faculty of Theology

University of Ljubljana

Matjaz.Celarc@teof.uni-lj.si

\author{
UDK: 299.725: 27-9“00“ \\ $27-248.2+27-312.5-056.153$ \\ $27-145.55+2-546.2$ \\ 616-036.84:2-184.85 \\ https://doi.org/10.34075/cs.56.4.9 \\ Pregledni rad \\ Rad zaprimljen 4/2021
}

\begin{abstract}
This article presents the reading of the first summary narrative account in the Acts of the Apostles by adopting Point of View Analysis with the Intertextual Reading of the Isaianic prophecies. The article thus sheds light on the nascent christian community that enjoys God's blessing through the healing works of the apostles and caring for their sick ones.

Keywords: point of view analysis, intertextual reading, Isaianic New Exodus, nascent community

\section{INTRODUCTION}

This article, using the narrative and intertextual approach, reads the third summary in the immediate context of the internal and outer conflict $(5: 1-11 ; 5: 17-42)$. This reading not only confirms the impression that the community enjoys God's blessing, as the reader acquires in the first two summaries, but moreover, it underlines the divine origin of the community that is attested to by the apostles' miracles and growth of the community, in spite of the obstacles.
\end{abstract}

\section{PREREgUisites FOR INTERPRETATION}

\subsection{Overview of the narrative context}

The third summary, by concluding the Ananias episode (Acts 5:1-11), underscores the authority of the apostles prior to the continuation of the conflict before the Sanhedrin (5:17-40). The growing conflict permeating the narrative section of Acts 3-5 arrives 
at a partial and moderate resolution. However, the third summary has a striking impact on the reader informing him or her about preference for the apostles over and against the authorities.

\subsection{Delimitation of the narrative unit}

The summary does not present any specific temporal marker with the exception of the stylistic change in verbal tense. A sequence of verbs in the imperfect tense ${ }^{1}$ again gives the impression of continuity thus distinguishing the summary from its context.

Concerning the criteria of space, the summary presents some specific elements. First, the reference to Solomon's portico in the Temple (5:12) echoes the gathering after the healing of the lame man (3:11). Taking it in general terms as a reference to the temple, the teaching place of the apostles $(2: 46 ; 3: 1)$ is reaffirmed and foreshadows the irony of the following episode (5:20-21.25). The reference to the broad streets and cities in the vicinity of Jerusalem (5:15-16) suggests that a new stage in the spread of Christianity is about to begin. In the following episode, the narrator uses the rich terminology of imprisonment ${ }^{2}$ to convey the desire of the authorities to hinder the apostles' mission. However, the prompt intervention of God (5:19) and Gamaliel (5:39) clarify what should prevail.

Concerning the criteria of character, the third summary focuses on the prophetic authority of the apostles displayed through signs and miracles (5:12) provoking both awe (5:13a) and praise (5:13b). As a result, the incorporation of the outcasts (5:14-16: the sick and those tormented by unclean spirits) increases their number. The community of the believers, consisting of men and women (5:14), reaffirms its original composition $(1: 14)$.

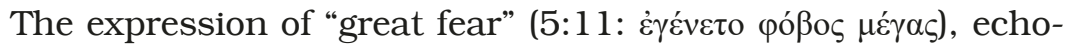
ing 5:5, forms an inclusion with the previous episode. Verse 5:12 introduces a new sequence through a series of stylistic elements: (1) the use of the particle $\delta \dot{\varepsilon}$, (2) a reference to hands and healing ( $\delta \grave{\alpha} \tau \tilde{\omega} v \chi \varepsilon i \rho \tilde{\omega} v)$ and (3) a change of the aorist into the imperfect. The formulation $\mu \dot{\varepsilon} v \ldots o$ oṽ $v^{3}$ in 5:41 displays the transitional function of the verse which concludes the episode by the subsequent summary statement (5:42).

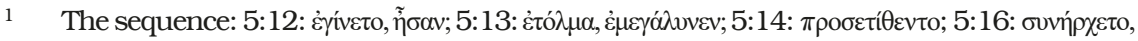
$\dot{\varepsilon} \theta \varepsilon \rho \alpha \pi \varepsilon v$ ovто.

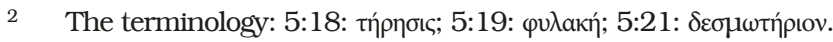

3 BDR § 451. 33. 


\section{Close REAding: Point of View Analysis}

\subsection{Perceptual facet}

Although the setting remains Jerusalem, the indication of Solomon's portico as the place of gathering $(5: 12)$ is telling for two correlated reasons: (1) the restoration of the people and (2) its universal implications.

(1) As to the first, placing the community within the temple as the core of Jewish socio-religious belief has ideological implications in terms of restoration, as has been already shown $(2: 46 ; 3: 1)$. (Keener 2013, 1031-1034) (2) Solomon's portico, where all the people gather (3:11), is, however, located at the magnificent entrance of the temple complex, permitting the crowd to mingle before entering the court of the Gentiles. (Josephus, Ant. 15,393) Yet this portrayal displays "a new self-articulation vis-à-vis the temple milieu/mentality," as Kisirinya $(2002,72)$ claims, foreshadowing the inauguration of the universal mission (Acts 1:8) for two already mentioned reasons: (1) Luke's relativisation of the role of the temple (Lk 19:46; Isa 56:7) and (2) the portico as a reminder of the Hellenistic schools of philosophy. (Evans 1990, 688; Wendel 1998, 170-171) In the final analysis, the position at the edge of the temple premises suggests that henceforth the Church is the mediator of the divine presence. Anthony Le Donne $(2013,349)$, observing the expectations presented in Acts 1-7, justly concludes: "The Lord's presence has extended beyond the Holy of Holies to the Portico of Solomon and eventually to the Gentiles at large." His understanding is supported by the narrative development of the summary itself. Not only the temple but also the streets become a place for Peter's movement and healings, and the people from surrounding cities gather in Jerusalem, as Codex D

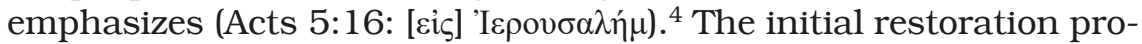
gram is reiterated as Wendel $(1998,102)$ observes, and "is beginning to be fulfilled" as Chambers $(2012,109)$ claims.

The tension between Jerusalem and the surrounding cities has a twofold apologetic goal: (1) portraying Christianity as an urban movement; and (2) indicating continuity with Judaism. (Pervo 2009,137 n. 108) Regarding this insight, Chambers $(2012,104)$ rightly concludes: "Luke reminds Gentile readers that their gospel was rooted in the faith of Israel even as their practice of meeting in homes (Acts 16:40; 17:7; 18:7-8; 20:20) transcended temple atten-

4 Whereas the text of $\mathrm{NA}^{27}$ is found in $\mathrm{P}^{74}, \mathrm{~N}, \mathrm{~A}, \mathrm{~B}$, the testimonies as $\mathrm{DE} \Psi$ add the preposition. 
dance and observances." Continuity, moreover, is emphasised by evoking the prophetic pattern of restoration in reference to Jerusalem (Isa 58:12; 62:1), as well as preparation of the way for the holy people (62:10-12). ${ }^{5}$ However, no earthly structure can circumscribe the Lord's sovereignty (cf. 43:1-2), as the Lord is in his heavenly abode (Isa 66:1-2; cf. Acts 7:49-50). (Childs 2001, 511-513)

\subsection{Psychological facet}

On the emotional plane of the psychological facet, the summary remains very indirect and subtle. However, alongside the unity (Acts 5:12) that has special relevance and despite Ananias' distortion of it (5:1-11), three additional elements conveying the dynamic of adherence are featured: (a) hindrance (5:13a), (b) favour (5:13b14) and (c) healing (5:15-16).

\section{Fearful reluctance}

An element of hindrance is linked to the verb ко $\lambda \lambda \dot{\alpha} \omega$ and can

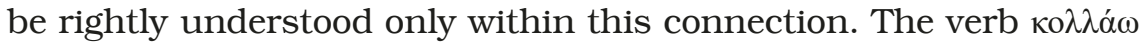
indicates (1) spatial, physical proximity or joining (8:29), as well as (2) social agreement with, adherence or allegiance to, a group of people $(9: 26 ; 10: 28)$ and $(3)$ a theological-antropological response to the proclamation of the apostles (2:38). The verb to "associate" thus opens up a threefold scholarly scaffolding.

(1) The spatial interpretation of ко $\lambda \lambda \alpha \dot{\omega}$ (cf. 8:29) as "physical proximity" proposed by Burchard (1970, 159-160) and Witherington $(1998,225)$, finds support in the foregoing episodes due to a "fear" (5:11), or prohibition (4:18), yet it fails to do complete justice to the following favour and growth (5:13b-14).

(2) The socio-religious interpretation relates the notion ко $\lambda \lambda \alpha \dot{\alpha} \omega$ in terms of "association" and "acceptance of the world-view of a certain group." Thus, Bruce (1990, 167), following both Blass' intriguing suggestion to interpret ко $\lambda \alpha \omega$ as "meddle;" as well as Pallis' emendation of the text by interpreting "the rest" as "the Levites," relates the reluctance to the fear felt by the Jerusalem populace.

(3) The theological interpretation of the notion is based on the surrounding context. While the immediate context reveals that the community is a divine creation (5:3) and only true believers can adhere $(5: 11)$, the remote context features a dynamic of fear and

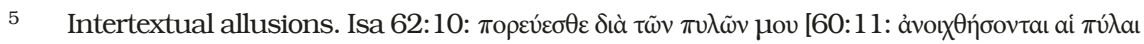

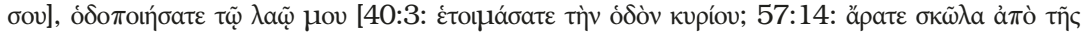

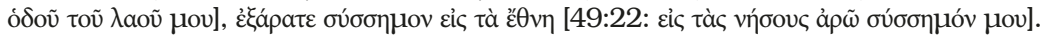


admiration (cf. 2:43; 5:1-11.12), which can result in either a divinely enhanced faith (5:14) or in an envious human hatred (5:17). Thus, association with the divinely formed community means to adhere to the divine call to salvation.

a) The rest of the people

The subject of this reluctance is indicated by the word "the rest." Some scholars, such as Rossé $(2010,83)$ associate "the rest" with the outsiders, or, such as Schneider $(1980,381)$, with unbelievers. Moreover, others as Jervell (1998, 202-203) speak of tension and separation within the people, or even, as Stählin (1973, 162163) relate the rest with "hostile minded Jews," or as Myllykovski (2006, 167-168), with the "majority of people," who feared the believers, in contrast to "a mighty minority" being added to the Lord.

On other hand, some scholars take more moderate standpoints. While González (2001, 81-82) relates "the rest" with remaining "sympathisers" and Burchard $(1970,159)$ speaks of "the curious outsiders," Schwartz $(1983,552)$ intends "the rest" as all possible believers who sympathize but do not adhere completely to the community (i.e., paralleling them with a gradual membership in Qumran, 1QS 6:17-23).

However, on a grammatical basis, the sequence in the summary

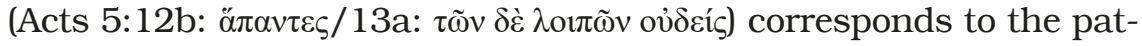
tern (group A/ [ $\delta \varepsilon$ ] group B) usually distinguishing two members one from another; 6 thereby distinguishing the community from "the rest." (Cunningham 1997, 186-203; Thompson 2008, 138-140) Moreover, the rest is distinguished from both: (1) the community $(5:[12 b] 13$ :

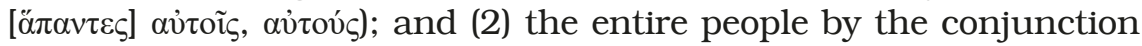
of opposition (5:13b: $\dot{\alpha} \lambda \lambda \dot{\alpha})^{7}$ and by the indefinite pronoun (5:13a: oủocíc). ${ }^{8}$

\begin{tabular}{|c|c|}
\hline 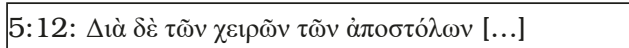 & 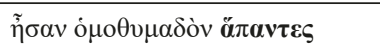 \\
\hline 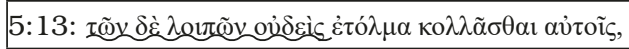 & 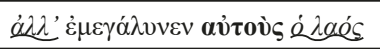 \\
\hline
\end{tabular}

The mysterious "rest" has prompted scholars to emend the text and relate the rest with the elders as Torrey $(1935,429)$ or with the Levites as Hilgenfeld (1899, 19). Matthew Sleeman (2009, 115-116), without emending the wording, come to a similar conclusion, as he observes the narrative plot of constant and growing conflict between

\footnotetext{
BDR $\S 447.1$.

BDR $§ 448.6$

BDR § 431.3. A substantive with partitive genitive. BAGD, 735.
} 
Jesus-space and temple-space and the people's sympathy towards the former group, relates the rest to the authorities. The narrative portrays the sympathy of the people (4:4), and the suspicion of the authorities (4:3). The perplexed and negative attitude of the authorities has extreme consequences. While at first, by disregarding God's purpose for his servants $(4: 28.30)$, they lay their hands on them and arrest them $(4: 3 ; 5: 18)$, ultimately, the authorities become victims of their moral disintegration displayed in their murderous drive (5:33). To sum up, the mysterious "rest" relates to the authorities. This forms as Brawley (1990, 94-106) rightly observes, two complementary narrative lines: (1) the gathering (5:14); and (2) the polemic and the sifting of the people (5:17).

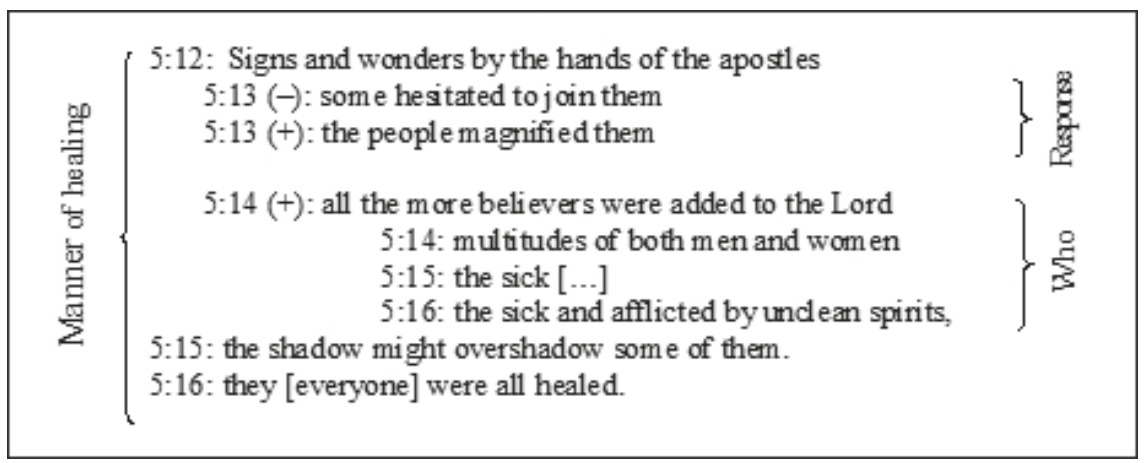

Figure: Variegated response

b) Favour of the people

The word "rest" alludes to the inner division within the people, displayed by both a negative and positive disposition towards the apostolic proclamation. Whereas reluctance to join the community characterizes the leaders or some of the people (5:13a), the people in general embrace a positive attitude towards the community (5:13b).

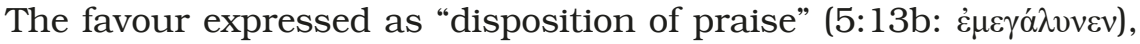
pervades the Lukan narrative (cf. Lk 1:46.58; Acts 2:11;10:46; 19:17) and evokes the Isaianic portrayal of the divine decision to magnify God's praise despite the people-servant's blindness (Isa 42:21:

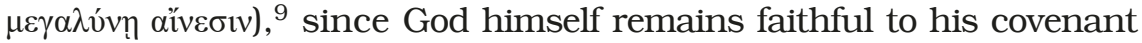
with his people. (Baltzer 1999, 151-152)

9 The Lord's praise (LXX: aiveбı) corresponds to his teaching, as the declaration of his will in the Law (MT: תורה). 
The crowd may be impressed by the harmonious unity of the community (cf. 5:12), yet the community depends on divine custody as confirmed by two elements: (1) the divine passive (5:14: $\pi \rho 0 \sigma \varepsilon \tau i \theta \varepsilon v \tau$ ); and (2) the characterization as believers in the Lord

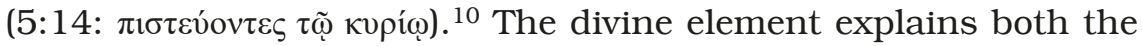
source $(5: 12.15 \mathrm{c})$ and the hopes of healing $(5: 15 \mathrm{ab})$. The believers entrusting themselves completely to the Lord are characterized not in quantitative but in qualitative terms as consisting of men and women (5:14). ${ }^{11}$ This anthropological pair reiterates the original circle of Jesus' disciples (cf. Lk 8:1-3; Acts 1:13-14) and evokes the remnant and restoration (cf. Jer 50:5-6; Neh 8:2f.). However, the Isaianic NE enters into this perspective as an echo only through Joel's

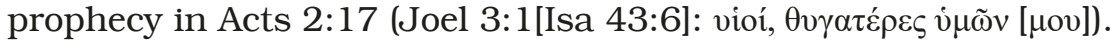

\subsection{Ideological facet}

The third summary portrays a restoration pattern through the theme of miraculous healings. Despite the socio-religious setting marked by miracle/magic expectations (cf. Acts 8:9-13), the healings portray that God continues to act mercifully towards people through the agency of the apostles. (Reimer 2002, 88-89; Marguerat 2003, 100-120; Pilch 2004, 49-51) In brief, the miracle stories and healings aim to show the divine source (4:29-30), and to evoke faith (4:4). These stories form: (1) apology, (2) syncrisis, (3) typology, and (4) prolepsis.

1) Miracles and healings confirm the apostles as authoritative agents of God (Acts 3:1-11; 4:29-30; cf. Isa 8:18; 35:6; 40:29-31). (O’Reilly 1987, 134; Nielsen 1987, 173 -182)

2) Healings are signs of Jesus' presence and authority, forming syncrisis between Jesus and his apostles. (Warrington 2006, 215-216)

3) Miracles introduce the exodus typology (cf. Acts 7:36), Thus, the miraculous healings are, in Lampe's (1966, 171) words "signs of the new age which the Ascension has inaugurated," as the instauration of God's reign (Lk 10:38).

4) The healings enable the mission to transcend socio-religious boundaries (Acts 1:8). (Klauck 2000, 14)

10 Cf. BAGD, 816-817. The formulation, $\pi \iota$ 18:8) in all but two of the instances in Luke-Acts (Lk 1:20; Acts 8:12).

11 For the socio-religious position of women, see Koch (2014, 63-64). 
The Isaianic text envisions the re-established socio-political condition as the prerequisite of healing (cf. Isa 33:24; 30:19ff.; 58:6; 65:17ff.), ${ }^{12}$ the primary role being taken by God (33:21-22), his messianic agent (33:17) and Servant (cf. 42:1; 53:4: 61:1-2; 58:6).

\subsubsection{Healing as restoration of life}

\section{Healings in the Hellenistic context}

The issue of health and healing in the summary enable the cross-cultural dialog. While health means in Pilch's $(1991,188)$ words, "a state of complete well-being and not merely the absence of disease and infirmity," illness is perceived as an influence of demonic spirits causing isolation. For that particular cultural milieu, the perception of life is intertwined with religion, magic and miracles. (Aune 2007, 377; Penner 2012, 125-173)

To disregard this fact would be "uncritical and naïve," as Witherington $(1998,224)$ observes. While failing health led a person, regardless of whether he or she was rich or poor, to lose his or her employment, function and social life, healing represented reestablishing a person's life and maintaining stability within society. Given that healing by professional physicians was expensive, as Pilch $(2004,183-200)$ observes, three ways of dealing with this issue were elaborated: official healing shrines, soothsayers and charismatics, as Theissen $(1983,234)$ points out. While the state promoted temples and healing shrines dedicated to Apollo or Asclepius and other healing divinities, groups on the fringes of society followed either socially integrated charismatic healers or they practised magic. In sum, the theme of healing lies at the heart of Hellenistic society. However, the summary displays how the apostles perpetuate Jesus' instauration of the kingdom of God. The healings, either by the hands of the apostles (Acts 5:12) or under Peter's shadow (5:15), indicate the presence of the kingdom of God.

c) Healing by hand

With regard to healing by hands, it corresponds either to the actual practice of laying hands on the sick (Lk 4:40; Acts 3:7), as proposed by Stählin $(1973,160-161)$, or it is a Semitic figurative expression $(7: 25 ; 11: 30)$, as observed by Barrett $(1994,273)$. The preposition $\delta$ ió shows that the apostles are "God's instruments for performing miracles and not the cause" (cf. 19:11), as Chambers

12 The suffering and exclusion due to disease is finished because of healing and the

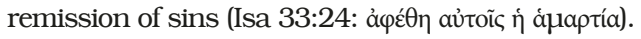


(2012, 102) observes. The insistence on the hands reveals Luke's interest and by intensifying the healing reference from Acts 2:43 forms a syncrisis with Jesus (Lk 4:40) and Paul (Acts 14:3). The linking motif of hands contrasts the apostles to the wicked who put Jesus to death $(2: 23)$ and associates them with Moses who provided salvation (7:25). The purpose is to portray them as the agents of God and thus an "extension of the hand of God that heals," in words of McCabe $(2011,14)$.

The healing points to the fact that God is present in the community and acts through his agents. (Muir and Coyle 1999, 85-97) The foregoing narrative stressed this fact in two points, as Grappe (1997, 117-132) observes:

(1) the Christological interpretation of Ps 15:8 (Acts 2:28-32) refers to the apostles by the gift of the Holy Spirit;

(2) the prayer of the community awaits the intervention of God's hand (4:30). The reference to healing as a sign of divine intervention evokes both the Hellenistic (Asclepius) ${ }^{13}$ and Jewish milieu (1QS 4:6-8).

Moreover, the terminology recalls the divine intervention in the Exodus (Deut 4:34) and eschatological renewal (Isa 35:6). However, the divine intervention includes his agent (53:5) and social sensitivity (58:6-9). Although the OT considers sorcerers to be false prophets (Deut 18:10-14) and officially rejects them (1Sam 28:3; cf. Isa 44:25), the phenomenon is reported (cf. Jub 48:9-11; CD 5:17-19; Rev 19:20). (Garrett 1989, 1-21) Given this social script that intertwines healing and magic, Luke endeavours to distinguish the dimensions. Thus, he omits the episode of Jesus' walking on the sea (Mt 14:22-33; Mk 6:45-52) but keeps the episode of calming the storm which reveals both Jesus' divine traits as well as the response of faith (Mt 8:23-27; Mk 4:35-41; Lk 8:22-25). Also, Acts unfolds the issue of magic as closely related to socio-economic profit (8:9-11; 16:16-17; 19:13-14); Luke, however, rejects it by affirming the anti-magical dimension (cf. Lk 11:20; Acts 4:12; 8:20-24; 16:18; 19:15-17). In brief, healing is not magic or pagan necromancy (Kelhoffer 2000, 268-271; Aune 2007, 389-407) but rather a sign of divine intervention. Depending on the response of faith (3:16), healing enacts salvation by redeeming a person from evil (cf. 2:40) in order to be a part of the community of the saved (cf. 2:47).

13 Gary Ferngren $(2009,25-35)$ concludes that secular medicine was easily assimilated into a Christian framework, because it was not dependent on a polytheistic worldview. 


\section{d) The healing power of Peter's shadow}

The power of Peter's shadow seems mythical and grants Peter an even more prominent role in the healing function. Regarding the meaning of the shadow, Horst's (1977, 206-210) analysis of it is revealing. In fact, Hellenistic culture gives special attention to a person's shadow, since it reflects a person and symbolises his vital part, the soul. Therefore, coming under the shadow of a criminal was noxious, but conversely the shadow of a god could bestow special power. In the OT a shadow symbolises greatness of reign (Ps 80:10; Isa 4:6) but is most commonly related to man's transience and death (Ps 22:4; 43:20; Isa 9:1). Besides, it also expresses divine presence or protection (Ps 56:2; Exod 40:35; Isa 38:8) and divine power (cf. Deut 33:12; 1Sam 16:13). One Isaianic instance displays the divine protection enjoyed by the people by combining the shadow and the

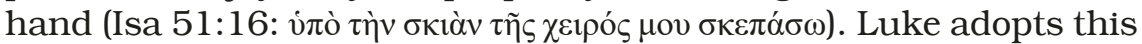

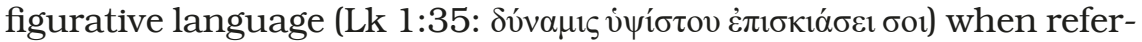
ring to divine power for the restoration of the people (cf. 1,51). In Acts, the apostles are empowered through Jesus' Spirit (Acts 1:8). (Witherington and Ice 2002, 115-127)

In the context of the third summary, Peter's shadow represents the power entrusted to him through the power of the divine Spirit. Peter embodies the divine power either to bless or to curse that leads to life or to death (cf. 5:5.10). ${ }^{14}$ It is not a psychological element or some kind of aura surrounding a great personality, but rather indicates the Christological element and the power of the Most High, as Bieder (1960, 407-409) proposes. This is confirmed by the formulation itself, distancing Peter's passing-by from the overshadowing of his shadow (5:13).

Briefly, the shadow emphasizes that Peter is a holy, even a divine man for both the biblical and Hellenistic worlds. The syncrisis between Jesus and the apostles (cf. 2:22), specifically Peter and Paul (Lk 6:19; Acts 5:12.15-16; 19:11-12), characterizes the apostles as divine men working miracles with divine power. The apostles and the community are divinely empowered. Their identity is confirmed in the conflict with the religious leaders as well as the avaricious magicians. To this end, Penner $(2012,152)$ justly observes how their identity is "constructed positively precisely through the loss of the identity for others in the text."

14 Strelan (2004, 191-195) refers to Euripides' Madness of Hercules. 


\subsubsection{Healings as a sign of the kingdom of God}

Luke makes a distinction between healing and exorcism (Lk

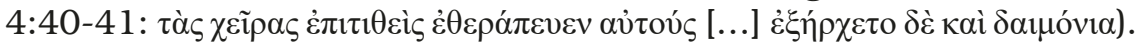
Concerning the latter, Strecker (2002, 126-128) designates exorcism as an illustration (Abbild) and archetype (Urbild) of the coming kingdom through transformation of the cosmic order, by eliciting an intersubjective social response. While demonic possession has a socio-political implication (cf. Acts 8:27.30), exorcism breaks the spell of the exclusion that results from possession (8:39) and provides the person with a new place in the social arena. Authority over demonic spirits has been given to the apostles (Lk 9:1; 10:17); however, its main purpose is salvation for the heavenly kingdom (cf. 10:20). In the third summary, the reference to healing and exorcism recalls Jesus' healings (Lk 6:18-19) and points to two dimensions of social involvement by: (1) bringing in the sick and possessed (Acts 5:15-16); and (2) overcoming social exclusion to form a new type

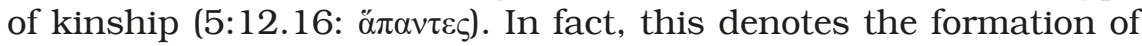
the community (cf. Acts $2: 7 ; 4: 31 ; 16: 28 ; 27: 33$ ). (Kee 1983, 194; Fitzmyer 2003, 260) Healing is an experience of salvation with social repercussions (cf. 2:46-47). Brandon Walker $(2014,133)$ applies this pattern to the expulsion of demonic forces and the social integration of the person as a symbolic act of bringing unity to Israel as the realisation of the Father's will.

To sum up this point, although these stories are marked by a cultural oscillation between magic and miracle, they not only provoke fascination but also foster devotion to God. The miracles performed by the apostles represent the continuation of Jesus' activity effecting the arrival of the kingdom (Lk 4:31-37; 5:12-16; 11:20) and reveal God's presence in the community. Thus, these actions evoke exodus typology (cf. Deut 7:15; Isa 35:3-6; 58:8; 65:19-20) as its eschatological realisation (cf. Acts 2:19-20). (Butticaz 2011, 145-147).

\section{SYNTHESIS}

The third summary is set between two narrative episodes which test the authority of the apostles both from within (5:1-11) and from outside the community (5:17-40). The function of the third summary is therefore to underscore the authority of the apostles. While the previous two summaries portrayed the apostles' authority in teaching and in the distribution of belongings within the 
community, and the third summary extends this pattern to include their numinous aura and healing power already famous outside Jerusalem.

The preliminary analysis presented a clear delimitation and pointed out both some lexical peculiarities and some difficulties of internal correlation. This study proposes to the scholarly field some narrative solutions deriving from the surrounding context. The insistence on healing through hands and shadow confirms the apostles as divine agents. The healings permit the outcasts to be incorporated into the restored community, which lives in harmony as a fulfilment of the Isaianic restoration.

For two reasons, the chapter gives special attention to the subsequent context: (1) the rhetorical force of persuasion by use of irony; and (2) the narrative inception of the parting of the ways. The leaders remain unable to respond positively to the divine sanctioning of prophetic authority to the apostles. The outrageous reaction of the Sanhedrin is held back by Gamaliel's wait-and-see principle. However, the conflict is not over but awaits the final rift. The intertextual reading of Isaiah shows how the restoration of the people, as portrayed in healing, implies divine and human action. However, the response of the people is divided. Blindness and deafness indicate the hardness of hearts that calls for conversion as the prerequisite for receiving the blessing.

In brief, this article has focused on the issue of healing raised by the summary which evokes the Isaianic NE. The portrayal of the restored people of God is offered through the prophetic activity of the apostles. This entails the sifting process, namely the acceptance of the faith through the conversion of fear into faith followed by joining the community of believers in the exalted Lord. The reading of the summaries reveals their narrative, apologetic and moral dimension in order to convey the image of the nascent Christian community as it enjoys God's blessing and is God's work. Just as Jesus finds support in Isaiah for the interpretation of his mission as the messianic servant, the community sees its mission as "servant" and its identity as "the people of God" as an echo of the Isaianic NE. The community, in following Jesus who entrusted his life to God (Lk 4), represents God's people. 


\section{Bibliography}

Aune, David E. 2007. "”Magic" in Early Christianity and Its Ancient Mediterranean Context. A Survey of Some Recent Scholarship “ Annali di Storia dell'Esegesi 24:229-294.

Baltzer, Klaus. 1999. Deutero-Jesaja. Gütersloh: Gütersloher Verlagshaus.

Barrett, Charles Kingsley. 1994. A Critical and Exegetical Commentary on The Acts of the Apostles. 1. Acts 1-14, International Critical Commentary. Edinburgh: T \& T Clark.

Bieder, Werner. 1960. "Der Petrusschatten, Apg. 5,15." Theologische Zeitschrift 16:407-409.

Brawley, Robert Lawson. 1990. Centering on God. Method and Message in Luke-Acts. Louisville KY: Westminster John Knox.

Bruce, Frederick Fyvie. 1990. The Acts of the Apostles. The Greek Text with Introduction and Commentary. 3 ed. London: The Tyndale Press.

Burchard, Christoph. 1970. "Fussnoten zum neutestamentlichen Griechisch.” Zeitschrift für die neutestamentliche Wissenschaft und die Kunde der älteren Kirche 61:157-171.

Butticaz, Simon David. 2011. L'identité de l'Eglise dans les Actes des apôtres. De la restauration d'Israël à la conquête universelle Vol. 174, Beihefte zur Zeitschift für die neutestamentliche Wissenschaft und die Kunde der älteren Kirche. Berlin: De Gruyter.

Chambers, Andy. 2012. Exemplary Life. A Theology of Church Life in Acts. Nashville (TN).

Childs, Brevard S. 2001. Isaiah, The Old Testament Library. Louisville KY: Westminster John Knox.

Cunningham, Scott. 1997. 'Through Many Tribulations.' The Theology of Persecution in Luke-Acts. Vol. 142, Journal for the Study of the New Testament Supplement. Sheffield: Academic Press.

Evans, Christopher F. 1990. Saint Luke. London: SCM.

Ferngren, Gary B. 2009. Medicine \& Health Care in Early Christianity. Baltimore: Johns Hopkins University Press.

Fitzmyer, Joseph A. 2003. Gli Atti degli Apostoli. Introduzione e commento. Brescia: Queriniana.

Garrett, Susan R. 1989. The Demise of the Devil. Magic and the Demonic in Luke's Writings. Minneapolis: Fortress Press.

González, Justo L. 2001. Acts. The Gospel of the Spirit. New York: Orbis Books.

Grappe, Christian. 1997. "Main de Dieu et mains des apôtres: Réflexions à partir d'Actes 4,30 et 5,12." In La Main de Dieu. Die Hand Gottes, edited by René Kieffer and Jan Bergman, 117-134. Tübingen

Hilgenfeld, Adolf Bernhard Christoph Christian. 1899. Acta Apostolorum graece et latine secundum antiquissimos testes. Berolini: Sumptibus Georgii Reimeri.

Horst, Pieter Willem van der. 1977. "Peter's Shadow: The Religio-Historical Background of Acts V. 15.” New Testament Studies 23.2:204-212. 
Matjaž Celarc, Narrative summaries in Acts of the Apostles Reading of the third ...

Jervell, Jacob Stephan. 1998. Die Apostelgeschichte. Göttingen: Vandenhoeck \& Ruprecht.

Kee, Howard Clark. 1983. Miracle in the Early Christian World. A Study in Sociohistorical Method. New Haven: Yale University Press.

Keener, Craig S. 2013. Acts. An Exegetical Commentary. 3:1-14:28. Vol. 2. Grand Rapids MI: Baker Academic.

Kelhoffer, James A. 2000. Miracle and Mission. The Authentication of Missionaries and Their Message in the Longer Ending of Mark. Vol. 2.112, Wissenschaftliche Untersuchungen zum Neuen Testament. Tübingen: Mohr Siebeck.

Kisirinya, S.K. 2002. "Re-Interpreting the Major Summaries (Acts 2:42-46; 4:32-35; 5:12-16).” African Christian Studies 18.1 (1):67-74.

Klauck, Hans-Josef. 2000. Magic and Paganism in Early Christianity. The World of the Acts of the Apostles. Edinburgh: T \& T Clark.

Koch, Dietrich-Alex. 2014. Geschichte des Urchristentums. Ein Lehrbuch. 2 ed. Göttingen: Vandenhoeck \& Ruprecht.

Lampe, Geoffrey William Hugo. 1966. "Miracles in the Acts of the Apostles." In Miracles. Cambridge Studies in Their Philosophy and History, edited by Charles Francis Digby Moule, 163-178. London: Mowbray.

Le Donne, Anthony. 2013. "The Improper Temple Offering of Ananias and Sapphira." New Testament Studies 59 (3):346-364. doi: doi:10.1017/ S0028688513000064.

Marguerat, Daniel. 2003. "Magic and Miracle in the Acts of the Apostles." In Magic in the Biblical World. From the Rod of Aaron to the Ring of Solomon, edited by Todd E. Klutz, 100-124. London: Sheffield Academic Press.

McCabe, David R. 2011. How to Kill Things with Words. Ananias and Sapphira under the Prophetic Speech-Act of Divine Judgement (Acts 4.325.1 1). Vol. 454, Library of New Testament Studies. London: T \& T Clark.

Muir, Steven C., and John Kevin Coyle. 1999. Healing in Religion and Society, from Hippocrates to the Puritans. Selected Studies. Lewiston NY: Edwin Mellen.

Myllykoski, Matti. 2006. "Being There: The Function of the Supernatural in Acts 1-12." In Wonders Never Cease. The Purpose of Narrating Miracle Stories in the New Testament and Its Religious Environment, edited by Michael ed Labahn and Bert Jan ed Lietaert Peerbolte, 146-179. London: T\&T Clark.

Nielsen, Helge Kjaer. 1987. Heilung und Verkündigung. Das Verständnis der Heilung und ihres Verhältnisses zur Verkündigung bei Jesus und in der ältesten Kirche. Vol. 22, Acta Theologica Danica. Leiden: Brill.

O'Reilly, Leo. 1987. Word and Sign in the Acts of the Apostles. A Study in Lucan Theology. Vol. 243, Analecta Gregoriana. Roma: Pontificia Universitas Gregoriana.

Penner, Todd C. 2012. "Res Gestae Divi Christi. Miracles, Early Christian Heroes, and the Discourse of Power in Acts." In Miracle discourse in the New Testament, edited by Duane Frederick Watson, 125-173. Atlanta GA: Society of Biblical Literature. 
Pervo, Richard I. 2009. Acts. A Commentary. Minneapolis MN: Fortress. Pilch, John J. 1991. "Sickness and Healing in Luke-Acts." In The Social World of Luke-Acts. Models for Interpretation, edited by Jerome $\mathrm{H}$. Neyrey, 181-209. Peabody MA: Hendrickson.

Pilch, John J. 2004. Visions and Healing in the Acts of the Apostles. How the Early Believers Experiented God. Collegeville MN: Liturgical Press.

Reimer, Andy M. 2002. Miracle and Magic. A Study in the Acts of the Apostles and the Life of Apollonius of Tyana. Vol. 235, Journal for the Study of the New Testament Supplement. London: Sheffield Academic Press.

Rossé, Gérard. 2010. Atti degli Apostoli. Introduzione, traduzione e commento. Vol. 41, Nuova versione della Bibbia dai testi antichi. Cinisello Balsamo: San Paolo.

Schneider, Gerhard J. 1980. Die Apostelgeschichte. 1. Teil. Freiburg: Herder. Schwartz, Daniel R. 1983. "Non-Joining Sympathizers (Acts 5,13-14)." Biblica 64 (4):550-555.

Sleeman, Matthew. 2009. Geography and the Ascension Narrative in Acts. Vol. 146, Society for the New Testament Studies Monograph Series. Cambridge: Cambridge University Press.

Stählin, Gustav. 1973. Gli Atti degli Apostoli. Brescia: Paideia.

Strecker, Christian. 2002. "Jesus and the Demoniacs." In The Social Setting of Jesus and the Gospels, edited by Wolfgang Stegemann, Gerd Theissen and Bruce J. Malina, 117-133. Minneapolis MN: Fortress Press.

Strelan, Rick. 2004. Strange Acts. Studies in the Cultural World of the Acts of the Apostles. Berlin: Walter de Gruyter.

Theissen, Gerd. 1983 [1973]. The Miracle Stories of the Early Christian Tradition. Translated by John Kenneth Riches and Francis McDonald. Philadelphia: Fortress.

Thompson, J. Alan. 2008. One Lord, One People. The Unity of the Church in Acts in its Literary Setting. Vol. 359, Library of New Testament Studies. London: T \& T Clark.

Torrey, Charles Cutler. 1935. "'The Rest' in Acts V. 13." The Expository Times 46.9:428-429.

Walker, Brandon. 2014. "The Forgotten Kingdom: Miracle, the Memory of Jesus, and Counter-Ideology to the Roman Empire." In Reactions to Empire. Sacred Texts in their Socio-Political Contexts, edited by John Anthony Dunne and Dan Batovici, 129-146. Tübingen: Mohr Siebeck.

Warrington, Keith. 2006. “Acts and the Healing Narratives: Why?” Journal of Pentecostal Theology 14 (2):189-217.

Wendel, Ulrich. 1998. Gemeinde in Kraft. Das Gemeindeverständnis in den Summarien der Apostelgeschichte. Vol. 20, Neukirchener theologische Dissertationen und Habilitationen. Neukirchen-Vluyn: Neukirchener Verlag.

Witherington, Ben, and Laura Michaels Ice. 2002. The Shadow of the Almighty. Father, Son and Spirit in Biblical Perspective. Grand Rapids MI: Eerdmans.

Witherington, Ben, III. 1998. The Acts of the Apostles. A Socio-Rhetorical Commentary. Grand Rapids MI: Eerdmans. 